\title{
Analysis of Snare of Law for "Pay Day Loan" Providers According to Indonesian Criminal Law
}

\begin{abstract}
Pudji Astuti $^{1}$
${ }^{1}$ Universitas Negeri Surabaya

*Corresponding author. Email: pudjiastuti@unesa.ac.id

ABSTRACT

Financial Services Managers have been regulated in Law Number 21 of 2011 concerning the Financial Services Authority (OJK Law). The goal is to grow the country's economy by providing opportunities for financial service managers who are able to carry out activities to grow the national economy in a sustainable manner and protect the interests of consumers. Unfortunately, there are many illegal financial service managers who harm consumers by providing loans in the form of high interest Payday Loans, non-transparent administrative management and a random collection system to the numbers listed in the borrower's contact list using swear words that are not worth hearing. This issue is crucial because the government has not been able to protect Borrowers properly, considering that the Financial Services Authority (OJK) and the Investment Alert Task Force in charge of overseeing the management of financial services are only entitled and obliged to handle legal financial services managers and even then can only withdraw their permits. Therefore Lander should be charged with the provisions of the Criminal Law as regulated in the Criminal Code concerning Fraud, Extortion and defamation. If the money lent is proven to be the proceeds of crime, Lander can also be charged with the Crime of Money Laundering.
\end{abstract}

\section{Keywords: Pay day loan, Lender, Borrower}

\section{INTRODUCTION}

Advances in technology have resulted in changes in human life, the emergence of gadgets and the internet has an impact on communication that is not limited to the territory of a country. People can easily communicate and carry out activities in a short time such as without any national boundaries. The development of this technology also has an impact on the management of financial services which is commonly called Fintech (Financial Technology). The term Fintech is a company engaged in financial services by using the concept of financial technology to accelerate and facilitate aspects of the financial services it provides anywhere and anytime [1]. The definition of fintech according to the OJK Law is an innovation in the financial services industry that utilizes the use of technology [2]. Fintech products are usually in the form of a system built to carry out specific financial transaction mechanisms. The concept of financial technology (fintech) facilitates what is considered difficult and takes a lot of time and fulfills the needs and habits of humans who want "shortcuts" for various affairs [3]. For example, the activity of buying and selling goods no longer requires a meeting between the seller and the buyer, it is enough to communicate through the gadget, the goods can be directly received and the payment is transferred through the bank. Likewise, there are financial management services that can be done online, and now many people are talking about booming [4]. Lee \& Shin cited by Ryan Randi Suryono argue that Fintech is recognized as one of the most important innovations in the financial industry and is growing rapidly, driven in part by the sharing economy, regulation, and information technology[5]. Based on Information Technology Services released on December 28, 2016, the number of P2P landing companies that are registered or have permits and register their companies reach 40 entities, of course every year it can increase[6]

There are actually many researches on the topic of Fintech, Christian Hadad researching the Global Fintech Market [7], Hornuf and Hadad researching Fintech Transformation in Germany [8], Ryan Randi Suryono researching the challenges and trends of fintech [9] and Helen researched fintech related to financial access [10]. Previousresearchers generally focused more on the positive impact of fintech for entrepreneurs. While this research is more focused on the negative impact of fintech for borrowers who feel disadvantaged by the existence of illegal fintech. The result of this research is expected to be the basis of opportunities for other researchers to conduct more in-depth fintech research.

The management of financial services through online actually benefits debtors and creditors, because they don't have to encounter, just online everything can be resolved. Problems arise if the financial service manager does not meet the requirements set out in Law Number 21 of 2011 concerning the Financial Services Authority (OJK Law). Financial service managers who do not meet the requirements do not guarantee protection for their consumers. Article 4 of the Financial Services Authority Law regulates that: "The OJK Law aims to grow the country's economy by providing opportunities for 
activities in the financial services sector that are able to sustainably grow the national economy and protect the interests of consumers"[2]

In an effort to achieve the objectives of the OJK Law, the OJK was formed which has the functions, duties and authority to regulate and supervise activities in the financial services sector in an integrated, independent, and accountable manner. The problem is that the OJK Law only regulates consumer protection related to financial service managers whohave met the requirements and have received OJK approval to manage financial services. Meanwhile, financial service managers who do not meet the requirements or who do not get permission from the OJK in managing financial services (illegal financial service managers) are not bound by the provisions of the OJK Law. As a result, OJK feels that it does not have the rights and obligations to protect consumers who have suffered loses due to the treatment of illegal financial service managers.

At the moment, fintech has spread to all circles of society. Currently, FinTech is not only known among entrepreneurs but is also known by the public in general. [11]. As a result, there have been many occurrences of financial management services which in carrying out their activities cause losses to consumers. As reported by several television stations recently that many artists are deceived by the existence of financial management services in the form of Me Miles, there are also victims who are harmed by Fintech P2P Lending and Pay Day Loan financial services by spreading their bills to other people which he knows.

Victims who suffer losses due to the actions of illegal financial service managers are also Indonesian citizens who should receive state protection as regulated in Article 6 paragraph (1) of Law No. 23 of 1999 concerning Human Rights [12]. Therefore, it is necessary to discuss in this paper related to : a. Who is authorized to supervise the illegal Financial Services Manager ? b. Can managers of illegal financial services that harm consumers be subject to criminal sanctions ? c. What should the government do to protect victims of fraudulent financial service managers?

This research will discuss only the management of financial services through online in the form of Pay Day Loan. This type was chosen, because the main target of Pay Day Loans is the weak, who generally lack funds and do not understand the law, so they are easily tricked. Besides, the interest charged on Pay Day Loans is so high that it ensnares them. this often causes various problems.

\section{METHODS}

This research uses a normative legal research method with the juridical approach to analyze an act that is to be classified in the applicable criminal legislation. Research data in the form of primary and secondary legal materials obtained through literature study.

The primary legal materials used include: the Civil Code (KHUPdt), the Criminal Code (KUHP), Law no. 8 of 2010 concerning the Crime of Money Laundering, Law Number 21 of 2011 concerning the Financial Services Authority (OJK
Law), and the Decree of the OJK Board of Commissioners Number: 01/KDK.04/2013 concerning the Investment Alert Task Force [13]. While secondary legal materials are in the form of journals, books, articles related to fintech.

The collected materials are then analyzed to obtain input regarding legal snares that can be imposed on the Lender which is detrimental to the Borrower in terms of Indonesian Criminal Law.

\section{RESULTS AND DISCUSSION}

Financial Services is a term that is often used to indicate the types of services provided by the financial institution industry. The financial institution industry in question includes banks, insurance companies, securities, consumer finance companies, and credit card companies. One type of financial institution that is managed online is commonly called Fintech (Financial Technology). The emergence of Fintech in Indonesia aims to make it easier for people to make financial transactions online, improve financial literacy, and realize financial inclusion in Indonesia. Fintech companies in Indonesia are now dominated by startups with great potential. Therefore, Fintech is developing rapidly into various sectors such as payment gateways, wealth management, crowdfunding, lending and others.

Payment Gateway is a means that can facilitate transactions in e-commerce. Payment gateways are very helpful in facilitating the transaction process with a choice of various payment methods. This can happen because the payment gateway connects e-commerce with various banks in Indonesia. Digital Wallet is a means where service users can save money in the application and can be used for payment transactions at offline and online merchants. Wealth Management is a financial and wealth management service. Wealth Management can function as a personal finance manager. With wealth management owned, information such as amount, income, expenses, total debt, insurance and others can be consulted. Like a doctor. Social Crowdfunding is one of the most popular social business funding methods. A method that allows people to 'jointly' to realize social interests.

Lending is a financial service that is engaged in capital matters. In Lending, there are several segmentations in terms of the purpose of using loans, such as personal loans (consumptive) and business loans (productive). The nominal loan for consumer loans usually ranges from IDR 1-3 million with a minimum tenor of less than 1 week to 30 days and MSME capital loans whose nominal value can reach IDR 2 billion with a tenor of 1-24 months. The consumer loan segment is also known as Payday Loan, while for MSMEcapital loans of up to Rp. 2 billion, it is called Peer-to-Peer (P2P) Lending.

The differences between P2P Lending and Payday Loans include: the amount of interest charged on the loan, P2P Lending provides lower interest rates, starting from 5\% per year up to approximately $30 \%$ per year. While Payday Loan offers a daily interest of $1 \%$. If we calculate this interest in one year it reaches $300 \%$ per year. In addition, P2P Lending does 
not take advantage of interest fees, which are entirely owned by the lender. Even so, P2P Lending cuts administrative costs from borrowers, not from interest costs like Payday Loans. Therefore, in terms of segmentation, P2P Lending can be said to be easier and safer.

The requirements for becoming a Pay Day Loan financial service provider are regulated in the Financial Services Authority Regulation Number 77 /Pojk.01/2016 concerning Information Technology-Based Borrowing-Lending Services with the following requirements [14] : 1 . Must register and obtain a license from the OJK. 2. In the form of a legal entity, namely Limited Company (PT) or Koperasi. 3. Have a certain amount of capital. 4. Perform information technology-based services. 5. Meet the maximum limit for lending. 6. Mandatory to make periodic reports. 7. Must have competent manager in the field of information technology. 8. Have competent directors and commissioners in the financial services industry. 9. Have sta77 /Pojk.01/2016 concerning Information Technology-Based Borrowing-Lending Services standard operating procedures Article 11 of the Financial Services Authority Regulation Number [2].

Online financial service providers that do not meet the requirements are classified as illegal online financial service providers. For information, . The results of the OJK search and the Investment Alert Task Force since early 2018 until now, the Investment Alert Task Force (SWI) and Kemenkominfo (the Ministry of Communication and Information Technology, also known as the Ministry of ICT) have blocked 1,350 illegal fintech plat- forms (OJK, 2019a). Nearly ten times as many fintech platforms attempt to operate outside regulations as operate legally in Indonesia [5]. Base on available data show that 42 percent of entities (Illegal Fintech) are of unknown origin. While the other 22 percent are from Indonesia, 15 percent from the US, and 21 percent from various other countries. The problem is who has the authority to supervise illegal Financial Service Providers that have the potential to harm consumers?

\subsection{Authorized institutions and their authorities related to online financial service providers (Payday Loans)}

The Financial Services Authority (OJK) as the institution in charge of supervising the implementation of financial services has the authority to monitor the existence of illegal Fintech Payday Loans. OJK together with the Investment Alert Task Force regularly upload illegal Fintech Payday Loan data to anticipate victims. This is done because there are many illegal Fintech Payday Loan services that can be accessed on smartphone applications or websites, and offer loans on easy terms or with tempting lures. Thus trapping the victim.

Illegal fintechs often change names, making monitoring difficult. For this reason, OJK in addition to direct supervision, also provides contact service number 157 and email consumer@ojk.go.id or alertinvestasi@ojk.go to anticipate fraud and consumer losses due to using Illegal fintech services. . Another thing that the OJK and the Investment Alert Task Force do is to socialize various things that must be considered by the public before using financial services or digital investment. Things to note include: First, ensure that the service provider offering the loan has a license from the competent authority in accordance with the business activities being carried out. Second, ensure that service providers offering loan products are registered as marketing partners. Third, ensure that the inclusion of the logo of the government agency or institution in the media offering has been carried out in accordance with the provisions of the legislation. Fourth, first check the names of fintech registered with the OJK which can be seen through the website [15]

The characteristics of illegal fintech include: not having official permission, not having a clear identity and office address, providing online loan services very easily and information about interest or fines is not clear, unlimited interest, unlimited late payment penalties, collection does not know time limits, accesses all data on the mobile phone of service users (borrowers), embarrass, terror to borrowers (violence, insults, defamation to spread personal photos/videos of borrowers) and does not provide complaint services.

The conclusion that can be drawn from the description above is that OJK can supervise and close illegal fintech, but cannot help resolve the losses suffered by victims due to the illegal treatment of Fintech Payday Loans. This is due to the absence of the OJK's rights and obligations to be responsible for the implementation of financial services that operate without the OJK's permission. So that OJK only has the authority to anticipate the occurrence of more victims.

\subsection{Legal snares that can be imposed on illegal Payday Loanfinancial services implementers}

Payday Loan which is currently booming is indeed favored by some people because it has advantages for both parties. For lenders, fintech is a fund development with promising interest. The risk is also relative because lenders can also determine for themselves according to their respective preferences. For millennials, this product is also very suitable considering that this product is supported by digital technology. For borrowers, this Payday Loan certainly helps debtors to get alternative loans if the documents and collateral they have are adequate, but not in accordance with the provisions of conventional banks, this fintech can be the solution.

Payday Loan is a debt that is a legal act classified in the field of Civil Law. This means that the bond between the lender (creditor) and borrower (debtor) is based on an agreement regulated in Article 1320 of the Civil Law [16]. Where both parties mutually agree on the existence of an agreement that binds both parties [16]. And this agreement can only end if it happens: default, the time ends, the achievement is completed, both parties agree to end it.

This means that if there is a problem related to this debt, it will be resolved in a civil manner as well. In practice, the problem of implementing Payday Loans often crosses into the realm of criminal law. Such as billing methods that are threatening, doing random collections to numbers listed in the borrower's contact list using swear words that are not worth hearing, stealing borrower data that is used to threaten, not being transparent about loan fees and fines. 
The settlement of debts and receivables as a bond can basically be resolved in civil law, but if the implementation of a payday loan has violated criminal law, then lenders as perpetrators who violate the criminal law should be charged with the applicable criminal law and is violated. This is in accordance with the principle of legality regulated in Article 1 paragraph (1) of the Criminal Code (KUHP): "There is no act can be punished before there are rules that regulate it first". This means that Lenders can be punished if in the implementation of Payday Loans they have violated the criminal law [17].

The acts of lenders that can be snared with Criminal Law [17] include :

- A threatening billing method (extortion) violate Article 368 paragraph (1) Criminal Code and Article 29 of The Law on information and electronics

- Perform random billing to the number listed in the borrower's contact list by using swear words that are not worth hearing (defamation) violate Article 315 Criminal Code and Article 27paragraph (1) of The Law on information and electronics

- Not transparent about loan fees and penalties (fraud) violate Article 378 Criminal Code and Article 28 paragraph (1) of The Law on Information and Electronics

- Money laundering if it can be proven that the money lent comes from the proceeds of crime violate Money Laundering Law

\subsection{Government Actions to be taken in Order to Protect Victims of Fraudulent Financial Services Managers}

Payday Loan victims are increasing day by day. Data for the special complaint post for online loan victims during November 2018 owned by the Jakarta Legal Aid Institute (LBH) shows a fairly serious number, namely 5093 complaints related to online loans. The problems experienced by victims are related to very high interest rates, lack of personal data protection, and criminal acts experienced in the loan collection process. This is because there are no rules regarding legal protection and human rights for borrowers [6].

The government is handling the problem of online loan victims through the OJK and the Investigation Alert Task Force. They only supervise the management of Fintech loans and close illegal Fintechs. Likewise, if there is a legal Fintech that violates the Financial Services Authority Regulation Number 77/POJK.01/2016, then the OJK will revoke its operational license only. This is not quite successful in preventing the occurrence of fintech victims, because the existing policies have not been able to solve the problems experienced by borrowers.

The existing policies do not answer the needs of the borrower. First, the rules regarding the imposition of sanctions. Based on POJK Number 77/2016, the toughest sanction is revocation of permits, as a result, Pay day loans become illegal because their licenses are revoked, but continue to operate in the community. In fact, the OJK is not responsible for illegal
Payday loan applications. Second, there are no rules governing online loan interest. Even though the interest set by the lender is generally very high and unlimited, this is very burdensome for the borrower. Third, the lack of government supervision related to consumer dispute resolution mechanisms. Therefore, regulatory reform is needed to ensure legal certainty and protection of human rights for the community, especially users of online loan applications. In addition, it is necessary to immediately ratify the Personal Data Protection Bill, considering that one of the root problems of online loans is the lack of personal data protection which is the reference for other rules in guaranteeing human rights.

\section{CONCLUSION}

\subsection{Conclusions}

The conclusion from the description above is that the Fintech Payday Loan manager is under the OJK and the Investment Alert Task Force which is authorized to regulate, supervise and impose sanctions on legal Fintech in the form of revocation of operational licenses, while against illegal Fintech OJK and the Investment Alert Task Force only have the right to close.

The implementation of Fintech Payday Loans that violate the rules can be subject to criminal sanctions, even though debts and receivables are included in the realm of Civil Law, provided that in the implementation of Payday Loans, Lenders violate the Criminal Law, such as making threats during billing, defamation, fraud and money laundering. all of which fall within the realm of criminal law.

Efforts to prevent the number of victims from increasing, the government should draw up legislation that is able to anticipate the problems experienced by borrowers and immediately ratify the Law on the protection of personal data in order to protect the human rights of citizens.

\subsection{Suggestion}

The target of Fintech Payday Loans is the lower class people who are financially squeezed, so they are not careful and do not understand the process and risks of Fintech Pay Day Loans. The government's main task is to socialize fintech to the entire community so that they better understand and can choose the right type of fintech to choose if they need funds.

Disseminate legal remedies that can be taken by borrowers in the event of a violation in the realm of Criminal Law by the Lender. So that Borrowers are not afraid to defend their rights if they are violated, because the state protects the rights of every citizen

The government immediately harmonizes the law and fills legal voids related to fintech issues, especially those related to Payday Loans, thereby ensuring the security of both lenders and borrowers. 


\section{ACKNOWLEDGMENT}

The authors would like to thank the Faculty of Social Sciences and Law for facilitating this activity so that the authors get many benefits for scientific development.

\section{REFERENCES}

\section{[1] 2018 Ela Patriana \& \\ 少子化の要因 : 就業環境か価值観の変化かNo}

Title

$$
\text { 「ジャーナル」. }
$$

https://www.bertelsmann-

stiftung.de/fileadmin/files/BSt/Publikationen/GrauePublik ationen/MT_G

lobalization_Report_2018.pdf\%0Ahttp://eprints.lse.ac.uk/ 43447/1/India

_globalisation $\% 2 \mathrm{C}$

$$
\text { society }
$$

and

inequalities\%281sero\%29.pdf\%0Ahttps://www.quora.com /What-is-the.

[2] hendrik sudarmoko \& Afrizal, No 主観的健康感を中心とした在宅高齢者における 健康関連指標に関专る共分散構造分析Title, (2011) 113 .

[3] M. Narastri, "Financial Technology (Fintech) Di Indonesia Ditinjau Dari Perspektif Islam", Indones. Interdiscip. J. Sharia Econ., vol. 2, 2020, pp. 155-170, https://doi.org/10.31538/iijse.v2i2.513.

[4] A. Susilo, et al., "Coronavirus Disease 2019: Tinjauan Literatur Terkini”, J. Penyakit Dalam Indones., vol. 7, 2020, p. 45, https://doi.org/10.7454/jpdi.v7i1.415.

[5] R.R. Suryono, I. Budi, B. Purwandari, Detection of fintech P2P lending issues in Indonesia, Heliyon, vol. 7, 2021 , e06782. https://doi.org/10.1016/J.HELIYON.2021.E06782.

[6] R.R. Suryono, B. Purwandari, I. Budi, Peer to peer (P2P) lending problems and potential solutions: A systematic literature review, Procedia Comput. Sci., vol. 161, 2019, pp. 204-214, https://doi.org/10.1016/j.procs.2019.11.116.
[7] B. Brandl, L. Hornuf, "Where Did FinTechs Come From, and Where Do They Go? The Transformation of the Financial Industry in Germany After Digitalization", Front. Artif. Intell., vol. 3, 2020, pp. 1-12, https://doi.org/10.3389/frai.2020.00008.

[8] L. Hornuf, C. Haddad, "The Emergence of the Global Fintech Market: Economic and Technological Determinants Christian Haddad The Emergence of the Global Fintech Market: Economic and Technological Determinants Abstract", Small Bus. Econ., 2019, pp. 81105.

[9] R.R. Suryono, I. Budi, B. Purwandari, "Challenges and trends of financial technology (Fintech): A systematic literature review", Inf., vol. 11, 2020, pp. 1-20, https://doi.org/10.3390/info11120590.

[10] H. Bollaert, F. Lopez-de-Silanes, A. Schwienbacher, "Fintech and access to finance", J. Corp. Financ., vol. 68, 2021, 101941 https://doi.org/10.1016/J.JCORPFIN.2021.101941.

[11] 赵璟悠 1 王勇 2 张冠男 3, 3 (2018) 116-120.

[12] Presiden Republik Indonesia, Undang-Undang No. 39 Tahun 1999 Tentang: Hak Asasi Manusia, Undang. Republik Indones. Nomor 39 Tahun 1999 Tentang Hak Asasi Mns. (1999) 1-45.

[13] J. Heymann, A. Raub, A. Cassola, "Constitutional rights to education and their relationship to national policy and school enrolment", Int. J. Educ. Dev., vol. 39, 2014, pp. 121-131, https://doi.org/10.1016/j.ijedudev.2014.08.005.

[14] Otoritas Jasa Keuangan, Peraturan Otoritas Jasa Keuangan Nomor

77 /Pojk.01/2016 tentang Layanan Pinjam Meminjam

Uang Berbasis Teknologi Informasi, Otoritas Jasa

Keuangan, 2016, pp. 1-29,

https://www.ojk.go.id/id/regulasi/otoritas-jasa-

keuangan/peraturan-ojk/Documents/Pages/POJK-Nomor77-POJK.01- 2016/SAL - POJK Fintech.pdf.

[15] www.hukumonline.com, (2010) 1-51.

[16] B.I. Menikmati, D. Kehilangan, H. Kewargaan, (Berlaku, B. Golongan, T. Asing, B. Tionghoa, D.B. Golongan, T.) Pasal, Kitab Undang-undang Hukum Perdata (Burgerlijk Wetboek voor Indonesie) Buku Kesatu orang (n.d.).

[17] Presiden Republik Indonesia, Undang-Undang Nomor 1 Tahun 1946 Tentang KUHP, Kementeri. Kehakim. 5 (1958) 1-133. 